\title{
IL6 Receptor Antibody
}

National Cancer Institute

\section{Source}

National Cancer Institute. IL6 Receptor Antibody. NCI Thesaurus. Code C124046.

Any antibody that recognizes an interleukin 6 receptor protein. 